\title{
The Place of Knowledge: A Methodological Survey
}

\section{Citation}

Ophir, Adi and Steven Shapin. 1991. The place of knowledge: A methodological survey. Science in Context 4(1): 3-21.

\section{Published Version}

http://dx.doi.org/10.1017/S0269889700000132

\section{Permanent link}

http://nrs.harvard.edu/urn-3:HUL.InstRepos:3425891

\section{Terms of Use}

This article was downloaded from Harvard University's DASH repository, and is made available under the terms and conditions applicable to Other Posted Material, as set forth at http:// nrs.harvard.edu/urn-3:HUL.InstRepos:dash.current.terms-of-use\#LAA

\section{Share Your Story}

The Harvard community has made this article openly available.

Please share how this access benefits you. Submit a story.

\section{Accessibility}




\section{ADI OPHIR AND STEVEN SHAPIN \\ The Place of Knowledge
A Methodological Survey}

A generation ago scientific ideas floated free in the air, as historians gazed up at them in wonder and admiration. From time to time, historians agreed, the ideas that made up the body of scientific truth became incarnate: they were embedded into the fleshly forms of human culture and attached to particular times and places. How this incarnation occurred was a great mystery. How could spirit be made flesh? How did the transcendent and the timeless enter the forms of the mundane and the contingent? Platonist and providentialist perspectives offered ways of speaking about the mystery, but, in general, it remained unresolved at the core of orthodox idealist historiography. ${ }^{1}$

It is plausible that intellectuals are forever attracted to idealist orthodoxies. The picture of ideas floating free in the ether of transcendence is an appealing one, the more so to groups who make and trade intellectual goods, who prefer to portray those ideas as both timelessly true and potent, and who work to secure a position for themselves detached from the demands of mundane custom and commerce.

Nevertheless, idealist orthodoxy has rarely been without its opposition, even within the clerisy. In railing against the contemplative ideal Nietzsche argued that knowledge is related to diet, discipline, and the will to power. Marxist heresies have attached culture to meum et tuum with bands of steel, generating a countermystery of how the noncultural can conceive and beget the cultural, while tending to collapse into the old orthodoxy whenever confronting the domain of scientific truth. Classical anthropological and sociological theories of knowledge have displayed vigor in situating and historicizing "common sense," "ideology," the cultures of religion and art, and the knowledge of "others" - and failures of nerve in bringing down to earth what is regarded as true and objective.

\footnotetext{
${ }^{1}$ Among the most coherent and systematic Platonizing historiographies of science are those of Charles Gillispie (esp. 1960) and Alexandre Koyré (esp. 1968). For a recent Platonist dismissal of contextualist history of science, see Bechler: "all events and circumstances - be they social, political, religious, psychological, etc. - are accidental vis-à-vis the ideas they occasion. . . . The only way to explain the ideas is by showing their essentiality to the theory rather than their importance to the people" $(1987,87)$. And see Nagel 1986 for a characterization of objectivity as "the view from nowhere."
} 
It is, of course, always an option to situate knowledge by way of an exercise in denigration. Accordingly, if it is maintained that ideas have worth by virtue of the disconnectedness of their production from practical affairs or from the customs, conventions, and interests of particular cultural contexts, then the display of their location can be mobilized as criticism: the knowledge in question was not the genuine article after all. This is a means we use evaluatively to contrast "science," and other designations for fully general and objective knowledge, with lesser cultural species. Thus, for example, Emile Durkheim: "Religious beliefs in the less developed societies show the imprint of the soil upon which they are formed; today, the truths of science are independent of any local context" $(1972,88)$. For Chekhov, science was just that form of knowledge which could not be marked by the place of its production: "There is no national science just as there is no national multiplication table; what is national is no longer science" (quoted in Auden and Kronenberger 1962, 260). As we move down the scale of intellectual evaluation, so we find appropriate modalities of time and place: "it is so" becomes "peasants in eighteenth-century Périgord claim" (Latour 1987, chap. 1). Insofar as the move from common sense to science is seen as one of abstraction, then what counts as science can be reduced to "mere" common sense by showing that it is indeed generated and evaluated according to the exigencies of particular contexts, that its meaning is locally shaped, that its terms do not translate between contexts, or that its domain of application is not global. Denigration by contextualization is a major feature of everyday discourse, in lay society and in the specialized communities of academics. What, for example, is the force of the statutory tu quoque argument against relativism, other than its specification of the transcendence of proper knowledge?

Nevertheless, it is possible to question and to reject the rules of the game in terms of which the situatedness of knowledge counts as criticism. What if knowledge in general has an irremediably local dimension? What if it possesses its shape, meaning, reference, and domain of application by virtue of the physical, social, and cultural circumstances in which it is made, and in which it is used? If this is so, then explorations of the situatedness of knowledge shed their capacity to expose and acquire a matter-of-fact character. Indeed, Jean Lave's powerful analysis (1988) of the situated nature of lay arithmetical skills is aimed at securing a higher valuation of everyday knowledge rather than a lower valuation of the esoteric culture from which these skills are said to arise. In fact, it is through systematic suggestions of this general sort that current inquiries about the places of knowledge have their legitimacy. Recognition of the situated character of our most highly valued forms of knowledge, and especially of science, has come into prominence over the past twenty years or so. It has developed together with a number of distinct, though loosely connected, tendencies in the history of ideas, the sociology of knowledge, and currents in modern epistemology. It is these enterprises that have given point to questions about the situatedness of knowledge and that provide the academic constituencies for the results of such inquiries. Indeed, nothing could be more fitting than for the selected proceedings of a conference entitled "The Place of Knowledge" 
to be published by a journal whose title and stated aims summarize the very enterprises that gave rise to such an idea.

Within the history of science and allied disciplines, there has developed an influential localist genre, marked by attention to national and regional features of an enterprise once regarded as paradigmatically universal. Empirical work in the social history of science has approached the problem of place in a vigorous, if piecemeal, manner. If scientific truth was one, still the forms of its cultural manifestations might be many. And a longstanding tradition in cultural history licensed attention to the local manifestations of universal science. Idealist historiography easily assimilated notions of Weltanschauung, and practical identifications of national "styles of thought," even in science, were common from early in the nineteenth century. Platonizing (or essentializing) strategies could readily repair any apparent denigration. Picking his way between Marx and Weber in the 1930s, Robert Merton ([1938] 1970) identified the role of context in shaping what he termed "the foci of scientific interest" while adamantly asserting the self-sufficient autonomy of scientific method and knowledge. In the 1970s social historians of science such as J. B. Morrell and Arnold Thackray elaborated a program of research that focused on national and even municipal political and cultural circumstances in shaping the forms of scientific enterprise; and a growing number of practitioners simply took for granted the legitimacy of a local focus while putting to one side the epistemological questions that made such a focus most problematic. Attention to place in the history of science emerged partly out of a willingness to ignore the problem of knowledge. ${ }^{2}$

In more diffuse ways, the emergence from the 1960s of strong anti-empiricist and anti-individualist tendencies in the sociology and philosophy of science also contributed to the perceived interest and legitimacy of studying the place of scientific activity. In ideal-type empiricist schemata, an isolated individual, conceived as free, pure, and unconstrained, confronts a natural reality, conceived as transparent to his gaze. Within such a framework, the particular expectations, conventions, and interests transmitted to the individual from society can act only as sources of contamination and corruption. Empiricism built upon a widely distributed model of the philosopher as a solitary, a rational and perceptually competent unit, placed nowhere in particular on the map of culture. Few philosophers in the postwar period any longer defended such a "naive empiricist" view, but many wrote as if it were an accurate representation of scientific practice.

In the philosophy of science the formal, if not practical, discrediting of naive empiricism proceeded from Karl Popper to N. O. Hanson and thence to Thomas Kuhn. To varying extents, each writer modified the picture of the scientific observer as a solitary. He was now to be endowed with a set of theoretical expectations or presuppositions that structured his perceptions and judgments. Kuhn's (1970) portrayal was the most radical and had the greatest bearing on conceptions of the place of science. No longer did scientists confront reality outside the conventions of

${ }^{2}$ For representative works in this genre, see Thackray 1974, Morrell and Thackray 1981, Shapin 1972, Inkster and Morrell 1983, and Hunter 1989. 
their society: indeed, in Kuhn's view the institutions that regulated entry and that maintained order within the scientific community provided scientists with the resources and structures of their judgment. There was no dualistic contrast between the evidence of nature and the conventions and authority of particular social forms because it was only within such forms that nature was engaged. Society, and a fortiori the situatedness of knowledge in different social forms, was not to be viewed as "contamination," because the evaluative dualism setting reality and society in opposition was rejected. Thus, Kuhn's work offered resources for a program of research that related ontology and epistemology to the particularities of different places on the social map. Inspect different social forms and you will discover different patterns of scientific judgment.

Broadly similar sensibilities were to be found in the work of cultural anthropologists, pragmatist philosophers, and in the later writings of Ludwig Wittgenstein. And indeed through the 1970 s and 1980s a number of sociologists and social historians of science (mainly in Britain) labored to draw those sensibilities into a coherent relativist and contextualist approach to the study of science. In the relativist genre, two moves are of particular significance to appreciations of the place of science. First, relativists attempted to disengage the problem of truth and validity from the problem of credibility. It is improper, relativists argued, to conflate a general notion of what is "true" or "valid" with the particular standards used in various settings to render "true" or "valid" judgments. The credibility of any particular claim cannot be gauged by our judgments of its validity, since the writ of our standards may not run in other contexts. Analysts are enjoined to a "symmetrical" approach to the study of science: we are to proceed with our explanations in the same way irrespective of the "truth value" we may ascribe to different claims. For the most part historians of science are now inclined to put truth judgments to one side when they inquire into the meanings of ideas. Yet meaning too is increasingly thought to be a situated accomplishment, to be addressed by studying historical actors' practical activities in context. Thus the relativist agenda is also a program for localist studies: its object is the analysis of the grounds of local credibility. Indeed, in the form best known and most influential in the social study of science, relativism can be practically defined through the notion that all knowledge claims and judgments secure their credibility not through absolute standards but through the workings of local causes operating in contexts of judgment (e.g., Bloor 1976, chaps. 1-2).

Wittgensteinian influences strengthened the link between relativist studies of science and a localist focus. And in fact such influences were a major source for stress on the performative or pragmatic aspects of scientific discourse. Accordingly, the second major move in the relativist tradition bearing on the place of knowledge is an emphasis on the embeddedness of knowledge in streams of practical life that is characteristic of the late Wittgenstein (e.g., 1976). Proper applications of a term are not fixed by past usage or by what are taken to be its exemplars at any time and place. Usage is said to be constantly revisable in light of experience and in respect of decisions taken to change or to stabilize certain designations. Thus the application of 
natural kind terms, for example, is always a matter of local circumstances. The analyst would want to know a society's practical ends and its history in order to understand its classification of the world. Similarly, Wittgensteinian influences are evident in a contextualist approach to meaning. The meaning of terms was to be found solely in their use. Accordingly, for historians of ideas the text was no longer to be a sufficient warrant for construals of its meaning. Instead, they were to note how meaning was constructed by differently situated interpretative communities, rendering their interpretations for local purposes (Bloor 1983).

All these contextualizing resources may well have contributed to the potential interest of inquiries into the situatedness of knowledge. Nevertheless, within their own frames of reference they did not generate a research program into concrete aspects of that situation. There was no particular justification in the work of Kuhn or Wittgenstein, for example, for attending to the shape and distribution of rooms, houses, laboratories, libraries, clinics, or prisons, or the siting of knowledge-making activities within those places. Yet from early in the twentieth century, traditions in social anthropology were available for those inclined toward such inquiries. LévyBruhl claimed that the very concept of space as an abstract, immaterial, and homogeneous field in which items are situated is culturally variable: for the "primitive" space "is not so much imagined, as felt, and its various directions and positions will be qualitatively differentiated from one another" ([1923] 1966, 95-96). In Primitive Classification and The Elementary Forms of the Religious Life Durkheim argued that our divisions of space are social in origin: different societies mark and bound space differently (e.g., Durkheim and Mauss [1903] 1963, esp. 86-87; Durkheim [1912] 1976, 11-12). They model physical space upon social space, and in so doing use the former to express and sustain the order of society. More fundamentally, in Pierre Bourdieu's reading, Durkheim's "objectivist" approach to social reality proceeded on the basis of a "social topology." What was objective in the subject matter of sociology was not a set of agents and institutions but their relations, "which constitute a space of positions external to each other and defined by their proximity to, neighborhood with, or distance from each other" (Bourdieu 1989, 16; see also Bourdieu 1968). Spatial metaphors pervade Bourdieu's own work. Indeed, he has elaborated a systematic topology of "social space" and the cluster of more or less autonomous "fields" that constitute it (Bourdieu 1984, chaps. 3-4; Bourdieu 1985).

Although subject to extensive theoretical modification and qualification, Durkheim's general insight retained a central place in social anthropology through the century in the work of, among others, Evans-Pritchard and Mary Douglas (e.g., Evans-Pritchard 1940, chap. 3; Bourdieu [1971] 1973; Douglas 1978, 26; Ardener 1981). Spatial arrangements and social practices evolve together: as each is used to reinforce the rightness of the other, they develop a "fit" particular to the culture, a network of norms and sanctions holding them in place. Clark Cunningham's (1973) essay on the Atoni house is a particularly neat and accessible treatment of relations between divisions of domestic, social, and cosmological space. Lévi-Strauss notes that the circular layout of the Bororo village was so vital to the cultural life of the 
inhabitants that European missionaries quickly realized that the most effective way of destroying their culture was to make them move into new settlements with a radically different geometry: "they would then be, in every sense, dis-oriented" ([1955] 1970, 204). Maurice Halbwachs ([1950] 1980, esp. 128-41) assesses the spatial order of a house and "the stones of the city" as saturated sponges of "the collective memory"; while Frances Yates' study of the ancient art of memory (1966) similarly describes the role of spatially situated objects as mnemonic devices. Many anthropologists have noted the use of physical divisions of space to signal the boundary between the sacred and the profane, and to mark temporal passages from one social status to another (e.g., Turner 1967, 213-15; Turner 1974, 184-87). Ben-Amos's (1989) treatment of state rituals and ceremonies in nineteenth-century France offers a political perspective on spatiality and the sacred/profane distinction; Agnew (1986) deploys anthropological sensibilities in his superb account of the ritual separation of theater and market in seventheenth-century England; and Armstrong (1988) gives a Durkheimian analysis of the changing spatial layout of the modern general practitioner's office in relation to conceptions of illness and the sick individual. Norbert Elias' study of the social meaning of spatial divisions in the Parisian hôtel was an evident response to Durkheimian concerns (1983, chap. 3) and Sharon Traweek's account $(1988$, esp. 18-45, 157) of the spatial layout and spatiotemporal culture of modern high-energy physics laboratories acknowledges Durkheimian inspiration.

Meanwhile, traditions of work in sociology and social geography traced the spatial parameters of social interaction (e.g., Giddens 1984, chap. 3; Hägerstrand 1967; Jones and Eyles 1977; Pred 1981; Sommer 1969; Hall 1966). Richard Sennett's analysis of "dead public space" displays connections between the heightened visibility of persons in modern built environments (open-plan offices, visually permeable walls, etc.) and the rise of a culture of intimacy:

When everyone has each other under surveillance, sociability decreases, silence being the only form of protection. . . Human beings need to have some distance from intimate observation by others in order to feel sociable. Increase intimate contact and you decrease sociability. Here is the logic of one form of bureaucratic efficiency. (Sennett 1977, 15)

Symbolic interactionist sociology, broadly construed, always stressed the importance of place in structuring social interaction. Studies of the social structure of such everyday sites as restaurants have noted, for example, the "loss of understanding" that flows from barriers to face-to-face interaction; and research into drinking places has identified the regions in which sociability may flow or be obstructed (e.g., Whyte [1949] 1973; Cavan 1973). The symbolic interactionist tradition, as well as Erving Goffman's closely related work, documented the setting-dependency of notions of normality and deviance:

There are activities that are considered proper and appropriate at a given or expected time and in a given setting and surrounding that become absurd, open to 
ridicule and even stronger sanctions, if performed at other times and in other settings. (Birenbaum and Sagarin 1973, 65) ${ }^{3}$

And in a science studies setting Knorr-Cetina (1981, esp. 9-12) summarized the problems and potentials of stipulating the "contexts" of social interaction. The anthropologists, by and large, portrayed spatial divisions as the outcome of socially organized cognitive processes, the geographers pointed to the causal effect of spatial patterns on social relations, ${ }^{4}$ and the symbolic interactionists delineated the normative variability of places; yet none of these genres developed a systematic focus on the relationships between thought and its social setting. ${ }^{5}$ Nevertheless, there are ways of thinking about knowledge and place that build on and extend these sensibilities as well as contextualizing tendencies in science studies.

One way trades in what might be called a "physicalist" idiom. In a quite fundamental manner the conditions of our knowledge vary according to our placement in social and physical space. If we are on one side of an opaque and impassable boundary, we may have direct experience of what is available to be seen therein. If we are on the other, our experience has to be at best indirect and mediated by others, and at worst we will have no knowledge of what passes where we cannot go and cannot see (e.g., Ophir 1984, 1991; Shapin 1988). In empiricist schemata we are accustomed to place a very high value on knowledge secured by direct experience and a correspondingly lower value on knowledge acquired on the basis of others' relations. Thus the question of access to sites of knowledge-making maps onto a fundamental epistemological distinction. A division in the map of knowledge flows from placement in physical and social space: on the one side, immediate experience; on the other, reliance on authority and trust. Within knowledge-making sites, epistemological and disciplinary distinctions are related to spatial arrangements that differentiate degrees of visibility, directness of access to objects of research, facility of movement between workplaces, and density of interaction among persons occupying different positions at different locations. The highly original syntax analysis of relations in social space developed by Hillier and his collaborators at the Unit for Architectural Studies, University College, London, offers a methodology for systematic research in this area (Hillier and Hanson 1984; Hillier and Penn 1991).

Of course, the possibility of access to places where experience is on offer, or where knowledge is being made, is a matter not just of concrete but of culture. Solid - even practically impassable - boundaries may be made out of something as insubstantial as

\footnotetext{
${ }^{3}$ No academic has analyzed the moral heterogeneity of domestic spaces better than the playwright Alan Ayckbourn.

${ }^{4}$ Revel (1991) has shown how geographical knowledge itself is historically both a result of access to political space and a means of control over that space.

${ }^{5}$ In this connection one must note research by French classicists and anthropologists of ancient Greek culture. Although this work cannot be summarized here, such studies have displayed and systematically reconstructed structural relations among modes of spatial cognition, patterns of "mythical" and "protoscientific" thought, political and cultural institutions, and concrete spatial arrangements (e.g., Vernant and Detienne 1978, chap. 10; Vernant 1983, chap. 3; Vidal-Naquet and Lévêque [1964] 1983; VidalNaquet 1986, chaps. 1-3, 12-13).
} 
a piece of paper on which is inscribed "Do Not Enter" or "Authorized Personnel Only." In A Midsummer-Night's Dream Bottom constructs the wall needed by Pyramus and Thisby out of little more than gesture and symbol:

Some man or other must present wall: and let him have some plaster ... to signify wall; and let him hold his fingers thus, and through that cranny shall Pyramus and Thisby whisper. (III, i)

For Goffman, as for the symbolic interactionists, the timing and spacing of social interaction is vital. The architecture of places is relevant to his sociological practice because settings focus "specific types of available co-presence" and it is co-presence that formed his major object of study. Movement in specific regions carries with it an expectation of sensitivity to local boundaries. Sometimes such boundaries are total, wholly encapsulating social interaction within them; sometimes they are partial and certain forms of communication may occur across them. Anthony Giddens' commentary on Goffman's work draws out the necessary relationship between the physical and the cultural in social orientation toward boundaries:

Physical divisions, such as the walls between rooms, tend to be treated as though communication were cut off from the outside regardless of how far in fact this is the case. Walls are socially respected communication barriers as much as they are purely material divisions between the enactment of various forms of encounters. Eavesdropping is a breach of the tact which is expected to be displayed in respect of encounters of which one is not a part. (Giddens 1988, 260-61, 265; Giddens 1987, 125; cf. Strong 1988)

Public entry to modern scientific laboratories is effectively restricted without (for the most part) laws, rules, or signs - merely by the circulation of knowledge that one has no legitimate place there and is unlikely to be made welcome, save on designated days of "Open House" (Traweek 1988, 21-24). By contrast, while concrete structures generally possess durability in relation to cultural practices (e.g., Halbwachs [1950] 1980, 128-57), ${ }^{6}$ their ability to restrict access is utterly dependent upon the energies mobilized by social practice. When this piece of writing was started, the Berlin Wall stood as a durable concrete obstacle, preventing inhabitants on either side from direct knowledge of opposed realities. As the writing was finished, bits of that wall were being sold as curios in the mini-malls of Southern California.

Physical divisions in space - and whatever resistances they offer to social transactions - are saturated with culture and they exist as symbols within our culture. It counts as a physical fact that we cannot see through an opaque boundary, yet the recognition of such an obstacle as "wall" or "door," as natural or artifactual, as prescribing different codes of correct conduct on either side, and the identification of

\footnotetext{
- In the debates over rebuilding the House of Commons after the Blitz, Winston Churchill was concerned that even minor changes in its spatial configuration and dimensions might affect the nature of parliamentary political life: "We shape our buildings," he said, "and they shape us" (quoted in Hall 1966, $100)$. Markus (1982a) analyzes the range of discourses (of form, function, and space) requisite to interpreting the purposes of architecture in the Scottish Enlightenment; and Revel (1991) examines the considerable energy needed to make and maintain the space of an emerging nation-state.
} 
this wall or door as relevant to the occasion at hand, all exist in the domain of culture. Given the codes that regulate behavior in different settings, physically co-present actors may "not see" each other as effectively as if they were separated by a wall or were, indeed, "not there." There may be injunctions to avert one's gaze from superiors; inferiors may be invisible as relevant actors (Shapin 1989a). For these and other reasons the "physicalist" idiom needs to be supplemented by a "cultural" perspective on the place of knowledge. More radically still, several writers have denied the apparent dualism that refers to the relations between culture and physical place. Bruno Latour's sociology of a door (1988) offers a general appreciation of the combined human and material technologies that create and maintain asymmetries, and Michael Lynch (1991) uses ethnomethodological resources to dissolve questions about the physical place of scientific work into "topical contextures" which, he argues, "are no less material ... than the 'physical setting' of the laboratory; indeed, they are the physical setting."

When we point to the setting of knowledge-making activities, we stipulate at the same time those social relations and constellations of value that render the knowledge in question either authentic, safe, and valuable, or fraudulent, dangerous, and worthless (Shapin 1991). For instance, the early Christian tradition both valued and suspected solitude as a place of knowledge: temptation lurked in private places, but the desert was also a place for putting belief to a trial, for self-discipline, and for direct engagement with the divine. From the fifteenth and sixteenth centuries humanist thought stipulated a civic setting for intellectual work. Francis Bacon and the publicists of the new experimental program of mid-seventeenth-century England argued that the validity of natural knowledge flowed from public presences at its making and public goods as its outcome. Such a public presence would guarantee that experimental knowledge was reliable and authentic, and the privacy of certain scientific practices was widely cited as evidence of their defective character (Hannaway 1986; Shapin 1988).

But not just any "public" would serve this witnessing and warranting function. As has been argued elsewhere, the situation of much new experimental practice and discourse in the public rooms of gentlemen's houses effectively mobilized the codes of gentlemanly conduct as practical solutions to the problem of trust. The integrity of gentlemen and their social relations served as a practical voucher of the reliability of the knowledge issuing from their houses. Conversely, practitioners not able to recruit that code as an ally confronted problems of trust in their own empirical narrations (Shapin 1988, 1989a, 1989b). ${ }^{7}$ Into the late twentieth century the management of the perceived setting of knowledge-making remains an immensely important practical problem. How to ward off annoying and potentially destructive intrusions into the place of scientific work, while securing for that knowledge the public character that warrants its authenticity (Collins 1988; Gooding 1989)? In the case of intellectual

${ }^{7}$ Martin Rudwick's account of the Geological Society of London in the early nineteenth century (1985, 18-27) traces the relations between gentlemanly codes of conduct and the organization of proceedings in physical and social space. 
work whose worth is gauged by its individuality, how to publicly advertise the solitude of the place of knowledge? ${ }^{8}$

Goffman (1969, chap. 3) identified the privacy of much social action as a condition of its power and perceived legitimacy (cf. also Bok 1982; Luhrmann 1989). "Backstage" is the region where the effects visible "frontstage" are produced. The intrusion of backstage processes into public gaze runs the risk of eroding frontstage impression management; hence all public action - even that which most insists on the propriety of open access - needs to secure its private spaces. And nowhere is this requirement more evident than in the production of scientific knowledge, where the seepage of tales from the laboratory and the coffee room into public consciousness invariably acquires the character of exposé and denigration. ${ }^{9}$

In a different idiom, Michel Foucault has also shown how moral and political matters are inscribed in space. Foucault's studies of the clinic and the prison (1975, 1977) suggested that relative placement in a socially defined site and its peculiar visual field is implicated in the constitution of the subjects and objects of knowledge as well as in the constitution and exercise of power. Jeremy Bentham's Panopticon was an architectural form that allowed those in authority to see all without being seen by any. Indeed, this was the basis of their power. Correspondingly, those who are seen without seeing are others' subjects. A place from which one can see others without being seen may be a place of power (Ophir forthcoming). For Foucault spatial concerns were, as he said, an "obsession." The analysis of power would be an analysis of spaces: conditions of visibility, dispersion of bodies, points of contact, and lines of transmission. Power is inscribed in place and not in time, and it is from this perspective that its entanglement with the production of knowledge can best be understood: "Once knowledge can be analysed in terms of region, domain, implantation, displacement, transposition, one is able to capture the processes by which knowledge functions as a form of power and disseminates the effects of power" (Foucault 1980, 69). Foucauldian historiographic sensibilities similarly point to changes in the cultural practices in which architecture is implicated.$^{10}$ Before the end of the eighteenth century, Foucault claimed, the art of public building was to make

${ }^{8}$ Caroline Jones' treatment of Andy Warhol's studio (1991) shows how the advertised location of artmaking in a "factory" functioned as an anti-Romantic and anti-individualistic ideology; Svetlana Alpers (1988, esp. chap. 3) displays Rembrandt's studio as a complexly organized workshop; and Schaffer's account of the nineteenth-century astronomical observatory documents the dialectic between widely distributed images of the astronomer as an isolated observer on his "watchtower" and the emerging reality of his role as "manager of a mathematical workshop" (1988, 126-31; cf. Williams 1989, esp. 123, 131-33).

${ }^{9}$ Chandra Mukerji (1989, esp. 199-200) contrasts the textual world in which scientific knowledge is communicated to colleagues with the largely oral and face-to-face domain in which scientists give advice to governmental agencies. The point is well taken, although our understanding and appreciation of faceto. face interaction in modern science is still rudimentary.

10 In this connection see, for example, the Foucauldian treatment of the hospital emergency room by Kelly and Sanchez (1991), as well as suggestive remarks by Rosenberg (1987, esp. chap. 5) on the relationship between hospital architecture and theories of disease, Markus' (1982b, 1982c) studies of Scottish Enlightenment schools, hospitals, prisons, poorhouses and madhouses, Reed's (1982) work on classicism and social change in Georgian Edinburgh, Owens' resonant account (1985) of laboratory architecture and practical morals in nineteenth-century America, and various essays treating the architecture of the laboratory in James (1989). 
power - the king's, the lord's, the deity's - manifest. From that point on, however, the leading problem became how functionally to use "the disposition of space for economico-political ends." The functional differentiation of rooms in a house makes manifest new forms of power (Foucault 1980, 148-49). ${ }^{11}$

Foucault's contribution to this topic extends beyond his historical studies of the spatialization of power/knowledge. In The Order of Things (1970, xvii-xviii) and again in a posthumously published 1967 lecture (1986) Foucault introduced a concept with substantial potential for understanding the place of knowledge and its historical changes. In his usage a "heterotopia" is a heterogeneous topos, a relatively segregated place in which several spatial settings coexist, each being both concrete and symbolically loaded. Foucault identified the "principles" of heterotopias: (i) they are segregated places of a special kind, with fixed and controlled entrances and exits; (ii) they are linked to special slices of time; (iii) there are two or more distinct, socially activated spatial settings in the same place; (iv) their functions may change over time while the nature of the place as a mechanism for "doubling" space remains intact; and (v) the "other" space of heterotopias stands in some significant relation to the rest of ordinary social spaces, designating or marking them as illusionary or real, corrupted, sane, normal, healthy, and so on.

Every culture has its specific heterotopic sites, used for various and changing social purposes: theaters and cemeteries, places for rites de passage, and places to take a holiday. Some sites may turn heterotopic through historical transformations; others, however, are designed and designated as heterotopic from their conception, and their heterotopic nature lies at the heart of the social institutions embedded in them. While the validity of Foucault's speculative historical account of the development of heterotopias remains to be assessed, it would be interesting to explore one particular extension of his idea. It is arguable that in the modern West the sciences have been especially strongly linked to heterotopic sites. To be sure, since Plato's Academy (and probably before) formally constituted knowledge has had a relatively demarcated place in the overall culture, set apart both socially and physically. Yet it might be argued that before the sixteenth century sites of intellectual activity were rarely heterotopic in Foucault's sense. During the sixteenth and seventeenth centuries scientific sites increasingly inhabited and helped to delineate a special "space of appearances," distinct from the space of everyday objects. ${ }^{12}$ Within the confines of that special scientific space the objects of science were "localized"; their phenomenal aspects were carefully recorded and more or less systematically correlated with that which remained invisible. Seventeenth-century emphasis on observation and experimentation may mask a major function of these segregated places: forcing the invisible to manifest itself, to leave traces, to betray a hidden presence. Yet the

${ }^{11}$ Here Foucault acknowledges the work of such social historians as Braudel and Marc Bloch. More recently, the best social historical work on privacy is Ariès and Duby 1987.

${ }_{12}$ Almost needless to say, one notes here a tendency rather than a switch. Indeed, Shapin (1988) has documented considerable overlap between sites of English seventeenth-century experimental discourse and the public rooms of gentlemanly residences. 
invisible appears only to the eyes of those authorized to observe it. The heterotopic site is at one and the same time a mechanism of social exclusion and a means of epistemically constituting conditions of visibility. One space enclosed within the site is always a segment of an encompassing social space, with which it is contiguous, from which its agents come and to which they return. The "other" space is the one in which the objects of a science appear. It is the space in which such entities as "laws," "cells," "genes," "particles," "atmospheric pressure," and "mental illness" are made manifest and represented.

The development of modern science - both natural and human - is closely linked to the institutionalization of special heterotopic sites. By the mid-seventeenth century one could already point to the chemical laboratory and the mechanical operatory, the observatory, the botanical garden, and the room of curiosities (e.g., Impey and MacGregor 1985). Other sites were established later, particularly in the nineteenth and twentieth centuries: panopticons, medical and psychiatric clinics, psychophysical laboratories, zoological gardens, new specialized museums, and also formally constituted geological and archaeological sites. The specific location, the level of segregation and interconnection with outer space, the inner spatial layout, and the modes of correlation between the visible and the invisible of these epistemic heterotopias have all been continually contested. Yet the fundamentally heterotopic nature of such sites appears as a pervasive and interesting feature of much scientific activity, at least since the seventeenth century. The "doubling" of space in the places of knowledge means that two people looking at the same spot on the ground, at the contents of the same glass receiver, or at the same illuminated screen might construe two different objects. And this "double-vision" would flow from the fact that the one person is an officially competent and authorized inhabitant of the space while the other is a visitor or a support worker. Nor do modern sensibilities regard this phenomenon as anything out of the ordinary. Indeed, Lynch notes (1991) that it requires anthropological disengagement to render the heterotopic status of the laboratory visible and problematic.

All sorts of qualifications to this account immediately, and legitimately, present themselves. For example, as noted earlier, epistemic heterotopias may well have existed in one form or another prior to the sixteenth and seventeenth centuries, and further study of such sites as monasteries, colleges, law courts, and observatories in ancient and medieval Europe can test and modify the particular historical claim. In fact, Foucault himself refers to one epistemic heterotopia - the library - that definitely existed prior to the seventeenth century but that, he says, only from the nineteenth century manifested the desire "to enclose in one place all times, all epochs, all forms, all tastes, [and] the idea of constituting a place of all times that is itself outside of time and inaccessible to its ravages" $(1986,26)$. The library could have become truly heterotopic only after the opposition between text and nature was securely established and representation became the mode of relation between them. According to Foucault (1970, chaps. 2-3), this was not the case prior to the sixteenth century (cf. Ophir 1991). As for the library as a place for the spatialization of history, 
this arguably waited until a clear demarcation between the ancient and modern was set in place. Perhaps this did not occur before the late eighteenth century, when Western consciousness was historicized, at once related to, and dramatically separated from, its own past.

Moreover, heterotopias have never characterized all forms of scientific activity. It is worth pursuing the speculation that the traditional, and problematic, opposition between the natural and the human sciences - Naturwissenschaften and Geisteswissenschaften - can be partially reformulated on the basis of distinctions between heterotopic and nonheterotopic places of knowledge. ${ }^{13}$ It might be argued that some intellectual practices, such as history, qualitative sociology, theoretical physics, oceanography, or, as Revel (1991) has shown, geography, are placed somewhere in a designated cultural space - a campus, a research institute. Yet that site is but another workplace, like the post office or the car factory. The objects of those sciences appear elsewhere, in places that are only contingently linked to the epistemic site, even when it takes a complex political and intellectual apparatus to establish those links. By contrast, such sciences as molecular biology, artificial intelligence, philology, and experimental physics are.largely set in heterotopias that constitute the spaces in which their objects appear and are observed and manipulated. Furthermore, systematic and knowledge-constitutive passages link heterotopic and nonheterotopic sites of knowledge. Thus Peter Galison (1989) has suggested a triple division of physics that is reflected in the arrangement of physics buildings and rooms, and in which heterotopic and nonheterotopic sites are linked via a "trading zone" (cf. Traweek 1988, 33).

Struggle over divergent intellectual programs constantly involves negotiation and conflict over places of knowledge. Where should they be in relation to other sites of social activity? What should be the conditions of access to them? How should they be laid out internally? As these questions have received practical answers, so major problems in social action have been addressed and, in part, resolved. Thus the place of knowledge is implicated in the network of relations between knowledge and power, in the distribution of knowledge in society, in perceptions of its validity and legitimacy (Ezrahi 1990). And, even more fundamentally, identification of the place of knowledge is part of any inquiry concerning the ontological status of scientific objects and the epistemological standing of scientific statements. The place of knowledge lays down conditions for the appearance of the objects of science, for their validation as real, and for the terms on which they are knowable.

The success of a program dedicated to displaying the situatedness of knowledge generates its successor problem. How is it, if knowledge is indeed local, that certain forms of it appear global in domain of application? Is the global - or even the widely distributed - character of, for example, much scientific and mathematical knowledge an illusion? If it is the case that some knowledge spreads from one context to many,

${ }^{13}$ Compare, in this connection, Latour's treatment of laboratories as "centres of calculation" and "obligatory points of passages"- powerhouses whose potency is said to consist in their capacity to contain and manipulate scaled-down versions of the larger world (1987, chaps. 2,6$)$. 
how is that spread achieved, and what is the cause of its movement? Is its distribution a strong indication of its correspondence with reality, or is it properly read as reflecting the success of certain cultures in creating and spreading the very means and contexts of application? ${ }^{14}$ If satisfactory answers as yet elude us, still their recognition as questions testifies to the consequentiality of inquiries into the place of knowledge. Perhaps the days in which ideas floated free in the air are truly nearing an end. Perhaps, indeed, what we believed to be a heavenly place for knowledge we will come to see as the result of lateral movements between mundane places.

\section{References}

Agnew, Jean-Christophe. 1986. Worlds Apart: The Market and the Theater in AngloAmerican Thought, 1550-1750. Cambridge: Cambridge University Press.

Alpers, Svetlana. 1988. Rembrandt's Enterprise: The Studio and the Market. London: Thames and Hudson.

Ardener, Shirley. 1981. "Ground Rules and Social Maps for Women: An Introduction." In Women and Space: Ground Rules and Social Maps, edited by Ardener, chap. 1. London: Croom Helm.

Ariès, Philippe, and Georges Duby, eds. 1987. A History of Private Life, 4 vols., translated by Arthur Goldhammer. Cambridge, Mass.: Harvard University Press. Armstrong, David. 1988. "Space and Time in British General Practice." In Biomedicine Examined, edited by Margaret Lock and Deborah Gordon, 207-25. Dordrecht: Kluwer.

Auden, W. H., and Louis Kronenberger. 1962. The Faber Book of Aphorisms. London: Faber and Faber.

Bechler, Zev. 1987. "The Essence and Soul of the Seventeenth-Century Scientific Revolution." Science in Context 1:87-101.

Ben-Amos, Avner. 1989. "The Sacred Center of Power: Paris and the State Funerals of the French Third Republic." Paper presented at the International Workshop on the Place of Knowledge, Tel Aviv and Jerusalem, 15-18 May 1989.

Birenbaum, Arnold, and Edward Sagarin, eds. 1973. People and Places: The Sociology of the Familiar. New York: Praeger.

Bloor, David. 1976. Knowledge and Social Imagery. London: Routledge and Kegan Paul.

-1983. Wittgenstein: A Social Theory of Knowledge. London: Macmillan.

Bok, Sissela. 1982. Secrets: On the Ethics of Concealment and Revelation. Oxford: Oxford University Press.

\footnotetext{
"I In a useful synthesis of work by Kuhn, Foucault, J. R: Ravetz, Nancy Cartwright, Ian Hacking, and Bruno Latour, Joseph Rouse endorses a view of science as "local knowledge": "The local laboratory turns out to be the place where the empirical character of science is constructed through the experimenter's local, practical know-how. The resulting knowledge is extended outside the laboratory not by generalization to universal laws instantiable elsewhere, but by the adaptation of locally situated practices to new local contexts" (1987, chap. 4 [quoting 125]; cf. Geertz 1983, chap. 8).
} 
Bourdieu, Pierre. 1968. "Structuralism and Theory of Sociological Knowledge." Social Research 35:681-706.

- [1971] 1973. "The Berber House." Translated and excerpted in Rules and Meanings, edited by Mary Douglas, 98-110. Harmondsworth: Penguin.

- 1984. Distinction: A Social Critique of the Judgement of Taste, translated by Richard Nice. Cambridge, Mass.: Harvard University Press.

- 1985. "Social Space and the Genesis of the Group." Theory and Society $14: 723-44$.

- 1989. "Social Space and Symbolic Power." Sociological Theory 7:14-25.

Cavan, Sheeri. 1973. "Bar Sociability." In Birenbaum and Sagarin 1973, 143-54.

Collins, H. M. 1988. "Public Experiments and Displays of Virtuosity: The Core-Set Revisited." Social Studies of Science 18:725-48.

Cunningham, Clark E. 1973. "Order in the Atoni House." In Right \& Left: Essays in Symbolic Classification, edited by Rodney Needham, 204-38. Chicago: University of Chicago Press.

Douglas, Mary. 1978. Cultural Bias. Occasional Paper No. 34. London: Royal Anthropological Institute of Great Britain and Northern Ireland.

Drew, Paul, and Anthony Wootton, eds. 1988. Erving Goffman: Exploring the Interaction Order. Cambridge: Polity Press.

Durkheim, Emile. 1972. Selected Writings, edited and translated by Anthony Giddens. Cambridge: Cambridge University Press. (From review originally published in Année sociologique, 1899.)

- [1912] 1976. The Elementary Forms of the Religious Life, translated by Joseph Ward Swain, 2nd ed. London: George Allen and Unwin.

Durkheim, Emile, and Marcel Mauss. [1903] 1963. Primitive Classification, translated by Rodney Needham. Chicago: University of Chicago Press.

Elias, Norbert. 1983. The Court Society, translated by Edmund Jephcott. Oxford: Blackwell.

Evans-Pritchard, E. E. 1940. The Nuer: A Description of the Modes of Livelihood and Political Institutions of a Nilotic People. Oxford: Clarendon Press.

Ezrahi, Yaron. 1990. The Descent of Icarus: Science and the Transformation of Contemporary Democracy. Cambridge, Mass.: Harvard University Press.

Foucault, Michel. 1970. The Order of Things: An Archaeology of the Human Sciences. London: Tavistock.

- 1975. The Birth of the Clinic: An Archaeology of Medical Perception, translated by A. M. Sheridan-Smith. New York: Vintage.

- 1977. Discipline and Punish: The Birth of the Prison, translated by Alan Sheridan. New York: Vintage.

- 1980. Power/Knowledge: Selected Interviews and Other Writings 1972-1977, translated by Colin Gordon, Leo Marshall, John Mepham, and Kate Soper, edited by Colin Gordon. Brighton: Harvester.

-. 1986. "Of Other Spaces." Diacritics 16:22-27. 
Galison, Peter. 1989. "The Trading Zone: Coordination between Experiment and Theory in the Modern Laboratory." Paper presented at the International Workshop on The Place of Knowledge, Tel Aviv and Jerusalem, 15-18 May 1989.

Geertz, Clifford. 1983. Local Knowledge: Further Essays in Interpretative Anthropology. New York: Basic Books.

Giddens, Anthony. 1984. The Constitution of Society. Cambridge: Polity Press.

-. 1987. Social Theory and Modern Sociology. Cambridge: Polity Press.

. 1988. "Goffman as a Systematic Social Theorist." In Drew and Wootton 1988, $250-79$.

Gillispie, Charles Coulston. 1960. The Edge of Objectivity: An Essay in the History of Scientific Ideas. Princeton, N. J.: Princeton University Press.

Goffman, Erving. 1969. The Presentation of Self in Everyday Life. London: Allen Lane, Penguin Press.

Gooding, David. 1989. "History in the Laboratory: Can We Tell What Really Went On?" In James 1989, 63-82.

Hägerstrand, Torsten. 1967. Innovation Diffusion as a Spatial Process, translated by Allan Pred. Chicago: University of Chicago Press.

Halbwachs, Maurice. [1950] 1980. The Collective Memory, translated by Francis J.

Ditter Jr. and Vida Yazdi Ditter. New York: Harper.

Hall, Edward T. 1966. The Hidden Dimension. Garden City, N.Y.: Doubleday.

Hannaway, Owen. 1986. "Laboratory Design and the Aim of Science: Andreas

Libavius versus Tycho Brahe." Isis 77:585-610.

Hillier, Bill, and Julienne Hanson. 1984. The Social Logic of Space. Cambridge: Cambridge University Press.

Hillier, Bill, and Alan Penn. 1991. "Visible Colleges: Structure and Randomness in the Place of Discovery." Science in Context 4(1):23-49.

Hunter, Michael. 1989. Establishing the New Science: The Experience of the Early Royal Society. Woodbridge: The Boydell Press.

Impey, Oliver, and Arthur MacGregor, eds. 1985. The Origin of Museums: The Cabinet of Curiosities in Sixteenth-and Seventeenth-Century Europe. Oxford: Clarendon.

Inkster, Ian, and Jack Morrell, eds. 1983. Metropolis and Province: Science in British Culture 1780-1850. London: Hutchinson.

James, Frank A. J. L., ed. 1989. The Development of the Laboratory: Essays on the Place of Experiment in Industrial Civilisation. London: Macmillan.

Jones, Caroline A. 1991. "Andy Warhol's 'Factory': The Production Site, Its Context and Its Impact on the Work of Art." Science in Context 4(1):101-31.

Jones, Emrys, and John Eyles. 1977. An Introduction to Social Geography. Oxford: Oxford University Press.

Kelly, Michael, and Ricardo Sanchez. 1991. "The Space of the Ethical Practice of Emergency Medicine." Science in Context 4(1):79-100.

Knorr-Cetina, Karin. 1981. "Introduction: The Micro-Sociological Challenge of Macro-Sociology: Towards a Reconstruction of Social Theory and Methodology." 
In Advances in Social Theory and Methodology: Toward an Integration of Microand Macro-Sociologies, edited by Knorr-Cetina and A. V. Cicourel, 1-47. London: Routledge and Kegan Paul.

Koyré, Alexandre. 1968. Metaphysics and Measurement: Essays in the Scientific Revolution. Cambridge, Mass.: Harvard University Press.

Kuhn, Thomas S. 1970. The Structure of Scientific Revolutions, 2nd ed. Chicago: University of Chicago Press.

Latour, Bruno. 1987. Science in Action: How to Follow Scientists and Engineers through Society. Milton Keynes: Open University Press.

-. 1988. "Mixing Humans and Nonhumans Together: The Sociology of a DoorCloser." Social Problems 35:298-310.

Lave, Jean. 1988. Cognition in Practice: Mind, Mathematics and Culture in Everyday Life. Cambridge: Cambridge University Press.

Lévy-Bruhl, Lucien. [1923] 1966. Primitive Mentality, translated by Lilian A. Clare. Boston: Beacon.

Lévi-Strauss, Claude. [1955] 1970. Tristes tropiques: An Anthropological Study of Primitive Societies in Brazil, translated by John Russell. New York: Atheneum.

Luhrmann, T. M. 1989. "The Magic of Secrecy." Ethos 17:131-65.

Lynch, Michael. 1991. "Laboratory Space and the Technological Complex: An Investigation of Topical Contextures." Science in Context 4(1):51-78.

Markus, Thomas A., ed. 1982a. Order in Space and Society: Architectural Form and Its Context in the Scottish Enlightenment. Edinburgh: Mainstream.

- 1982b. "Buildings for the Sad, the Bad and the Mad in Urban Scotland, 1780-1830." In Markus 1982a, 25-114.

- 1982c. "The School as Machine: Working Class Scottish Education and the Glasgow Normal Seminary." In Markus 1982a, 201-61.

Merton, Robert K. [1938] 1970. Science, Technology and Society in SeventeenthCentury England. New York: Harper.

Morrell, Jack, and Arnold Thackray. 1981. Gentlemen of Science: Early Years of the British Association for the Advancement of Science. Oxford: Clarendon.

Mukerji, Chandra. 1989. A Fragile Power: Scientists and the State. Princeton, N. J.: Princeton University Press.

Nagel, Thomas. 1986. The View from Nowhere. New York: Oxford University Press. Ophir, Adi. 1984. "The City and the Space of Discourse: Plato's Republic - Textual Acts and Their Political Significance." Ph.D. diss., Boston University.

- 1991. "A Place of Knowledge Re-Created: The Library of Michel de Montaigne." Science in Context 4(1):163-89.

- Forthcoming. Plato's Invisible Cities: Discourse and Power in the Republic. London: Routledge.

Owens, Larry. 1985. "Pure and Sound Government: Laboratories, Gymnasia, and Playing Fields in Nineteenth-Century America." Isis 76:182-94.

Pred, Allan, ed. 1981. Space and Time in Geography: Essays Dedicated to Torsten Hägerstrand. Lund: CWK Gleerup. 
Reed, Peter. 1982. "Form and Context: A Study of Georgian Edinburgh." In Markus 1982a, 115-53.

Revel, Jacques, 1991. "Knowledge of the Territory." Science in Context 4(1):133-61. Rosenberg, Charles E. 1987. The Care of Strangers: The Rise of America's Hospital System. New York: Basic Books.

Rouse, Joseph. 1987. Knowledge and Power: Towards a Political Philosophy of Science. Ithaca, N.Y.: Cornell University Press.

Rudwick, Martin J. S. 1985. The Great Devonian Controversy: The Shaping of Scientific Knowledge among Gentlemanly Specialists. Chicago: University of Chicago Press.

Schaffer, Simon. 1988. "Astronomers Mark Time: Discipline and the Personal Equation." Science in Context 2:115-45.

Sennett, Richard. 1977. The Fall of Public Man. New York: Knopf.

Shapin, Steven. 1972. "The Pottery Philosophical Society, 1819-1835: An Examination of the Cultural Uses of Provincial Science." Science Studies 2:311-36.

- 1988. "The House of Experiment in Seventeenth-Century England." Isis 79:373-404.

- 1989a. "The Invisible Technician." American Scientist 77:554-63.

- 1989b. "Who was Robert Hooke?" In Robert Hooke: New Studies, edited by Michael Hunter and Simon Schaffer, 253-85. Woodbridge: The Boydell Press.

- 1991. " "The Mind Is Its Own Place': Science and Solitude in SeventeenthCentury England." Science in Context 4(1):191-218.

Sommer, Robert. 1969. Personal Space: The Behavioral Basis of Design. Englewood Cliffs, N.J.: Prentice-Hall.

Strong, P. M. 1988. "Minor Courtesies and Macro Structures." In Drew and Wootton 1988, 228-49.

Thackray, Arnold W. 1974. "Natural Knowledge in Cultural Context: The Manchester Model." American Historical Review 79:672-709.

Traweek, Sharon. 1988. Beamtimes and Lifetimes: The World of High Energy Physicists. Cambridge, Mass.: Harvard University Press.

Turner, Victor. 1967. The Forest of Symbols: Aspects of Ndembu Ritual. Ithaca, N.Y.: Cornell University Press.

- 1974. Drama, Fields, and Metaphors: Symbolic Action in Human Society. Ithaca, N.Y.: Cornell University Press.

Vernant, Jean-Pierre. 1983. Myth and Thought among the Greeks. London: Routledge and Kegan Paul.

Vernant, Jean-Pierre, and Marcel Detienne. 1978. Cunning Intelligence in Greek Culture and Society, translated by Janet Lloyd. Hassocks: Harvester.

Vidal-Naquet, Pierre. 1986. The Black Hunter: Forms of Thought and Forms of Society in the Greek World, translated by Andrew Szegedy-Maszak. Baltimore: Johns Hopkins University Press. 
Vidal-Naquet, Pierre, and Pierre Lévêque. [1964] 1983. Clisthène l'Athénien: Essai sur la représentation de l'espace et du temps dans la pensée politique grecque de la fin du VIe siècle à la mort de Platon. Paris: Macula.

Whyte, William Foote. [1949] 1973. "The Social Structure of the Restaurant." In Birenbaum and Sagarin 1973, 244-56.

Williams, Mari E. W. 1989. "Astronomical Observatories as Practical Space: The Case of Polkowa." In James 1989, 118-36.

Wittgenstein, Ludwig. 1976. Philosophical Investigations, translated by G. E. M. Anscombe. Oxford: Blackwell.

Yates, Frances A. 1966. The Art of Memory. London: Routledge.

The Cohn Institute for the History and Philosophy of Science and Ideas Tel Aviv University (A. O.)

Department of Sociology and Science Studies Program University of California, San Diego (S. S.) 